\title{
Siza Vieira em Évora Revisitar uma Experimentação
}

\begin{abstract}
R esumo: O projecto experimental de Siza em Évora - o Bairro da Malagueira (casas em banda com telhado em terraço) -, pela sua dimensão (1200 casas), duração (1977-2000), inovação em termos de tipologias de habitat e morfologia urbana, e consequentes implicaçães ideológicas e políticas, é objecto de uma pesquisa e avaliação sócio-arquitectónica. Os resultados desta pesquisa revelam que, entre uma posição racionalista e um cuidado pela arquitectura da casa, o compromisso de Siza permitiu, por um lado, criar um bairro com uma forte identidade e, por outro, respeitar os modos de habitar numa casa. Apesar da sua densidade e contiguidade, as casas da Malagueira possuem dois dos pré-requisitos que distinguem o habitat individual do habitat colectivo: uma entrada autónoma e ausência de vizinhos, quer em cima quer em baixo. Esta pesquisa salienta igualmente a importância, nesta habitação, de uma variável de importância aparentemente menor: o muro do pátio. A variação da sua altura opãe dois tipos de pátio: de um muro elevado resulta um pátio fechado e íntimo voltado para a casa, enquanto que um muro baixo dá origem a um pátio aberto que expẽe a casa à rua. Em contrapartida, a rudeza do acabamento do "aqueduto" (galerias de infra-estruturas - às quais Siza quis conferir um papel simbólico na unificação do bairro) e a não conclusão dos espaços públicos e equipamentos inicialmente projectados por Siza consumam algumas fragilidades, diminuindo o prestígio de um bairro que permanece um complexo residencial periférico.
\end{abstract}

Palavras-chave: arquitectura; avaliação; experimentação; modos de habitar; Siza Vieira

\section{As Casas em Banda, uma Problemática Intermédia}

Em Portugal, como na maioria dos países europeus, a moradia beneficia da preferência da maioria dos habitantes. A antiga questão das problemáticas relacionadas com o habitat torna-se mais complexa no âmbito da oposição entre os seus tipos (habitat individual ou colectivo), os estatutos residenciais (arrendatário ou proprietário) e a localização urbana (no centro da cidade ou na periferia). Por exemplo, habitar uma casa (habitat individual) pressupõe frequentemente uma localização periférica e um estatuto de proprietário, enquanto que o habitat colectivo existe tanto nos centros das cidades como nas periferias, usualmente em regime de arrendamento ou co-propriedade. Sabe-se, efectivamente, que o que leva a maioria das pessoas a habitar nas periferias é o elevado preço da habitação nos centros históricos. Não se deve, porém, subestimar a "fuga da cidade" por parte dos habitantes das classes médias dotados de meios económicos suficientes para poderem escolher o tipo, estatuto e local de residência. Além disso, em Portugal tal como noutros países da Europa do Sul, prolifera a moradia auto-construída e "clandestina", revelando a incapacidade das instituiçø̃es e do mercado legal em responder a esta procura (Guerra, Fonseca Ferreira, 1990).

A forte difusão e a popularidade da extensão do habitat individual retira credibilidade a esta tipologia de alojamento segundo a opinião de alguns especialistas, a começar pelos urbanistas, que condenam a ocupação extensiva de solos agrícolas, paisagem, infra-estruturas e aumentando os tempos de transporte provocados por esta forma de desenvolvimento insustentável. Mas a condenação não é menor por parte dos sociólogos, que, como

\footnotetext{
* Sociólogo, Investigador do Institut Parisien de Recherche Architecture, Urbanistique Société (IPRAUS-CNRS) da École d'Architecture de Paris-Belleville. Contacto: jean-michel.leger@paris-belleville.archi.fr

** Socióloga, Técnica Superior do Instituto da Segurança Social (ISS, I.P.). Contacto: gisela.m.matos@seg-social.pt
} 
Pierre Bourdieu, consideram que a pequena-burguesia "conspira sobre a sua própria desgraça" endividando-se em projectos demasiado ambiciosos para as suas posses (Bourdieu, 2000: 223).

A moradia é aceite pelos profissionais do planeamento e arquitectura apenas sob a forma de organização em banda, dominando o designado design urbano e a concepção arquitectónica, em oposição às reputadas "detached houses" sem qualquer forma urbana e sem arquitectura. Em Portugal, Espanha ou Itália, as cooperativas são os principais meios difusores desta tipologia de habitat, de acordo com um modelo de urbanização que é, simultaneamente, um modelo de acesso à propriedade, usado nomeadamente pelas classes médias nas periferias (Domingues, Leite, Matos, 1999).

A expansão das casas em banda no âmbito das cooperativas é interessante como tipo de habitat intermédio para as classes médias, mas que raramente dá lugar a um verdadeiro bairro. Em termos de densidade constitui uma terceira via, entre a densidade elevada do bairro colectivo e a baixa densidade do loteamento de moradias. Mas será que para a sociedade, a opção pelas casas em banda é realmente vantajosa, em termos de densidade e de custos de infra-estruturas? E quanto ao habitante, não perderá este as vantagens do habitat individual sem, no entanto, ganhar as do habitat de elevada densidade? Estas questões interpelam particularmente o conceito antropológico de limite: limites da contiguidade (relação: "chez soi"/ vizinhança) e de identidade (o meu bairro/a minha cidade), mas também limite entre repetitividade produtora de unidade, de igualdade e de uma diversidade decorrente de apropriações individuais.

No âmbito destas problemáticas destaca-se um caso: a Malagueira, em Évora, um bairro de mil e duzentas casas em banda (ou geminadas) cuja concepção é assegurada desde 1977 até hoje pelo arquitecto Álvaro Siza Vieira, uma continuidade fora do comum para uma aventura urbana e arquitectónica ela própria também singular. Qual é, então, a "lição" de Siza em Évora?
Em 1975 o arquitecto italiano Vittorio Gregotti reconhecia já, de forma perspicaz, Siza Vieira como "um dos dez arquitectos mundiais da sua geração capaz de transformar a arquitectura numa expressão autêntica, susceptível de surpreender um meio cultural estagnado" (Gregotti, 1976:42). Desde aí, Siza efectuou a obra que se conhece, alcançando a maior parte dos prémios de arquitectura internacionais e confirmando que figura claramente no top ten mundial da arquitectura, como Gregotti havia precocemente prognosticado. Não foi com o Projecto da Malagueira que Siza ganhou notoriedade além-fronteiras, mas este projecto foi desde logo reconhecido pela crítica internacional como um projecto emblemático em termos de produção de alojamento na Europa (Huet, 1976; Rayon, 1982; Frampton, 1987, 2000; Portas, 1987; Curtis, 1994). Em Évora, Siza Vieira chega mesmo a ser comparado ao arquitecto finlandês Alvar Aalto (1898-1976), pela maneira como este, meio século antes, levou em consideração a "situação" do projecto, isto é, o seu espaço e as condições económicas da sua realização. De facto, a composição urbana da Malagueira tem em atenção, de forma muito cuidada, o terreno, a paisagem e tecido envolvente. Além disso, o discurso arquitectónico de Siza é manifestamente moderno, racionalista, puro, porém introduz também no código arquitectónico moderno elementos tradicionais como a janela vernácula (portas e janelas sobre a rua compostas por duas partes independentes), a chaminé alta e a entrada em mármore.

Embora os primeiros projectos do plano de desenvolvimento de Évora previssem a construção de edifícios colectivos, programados antes da Revolução (1974), com a Malagueira Siza leva ao limite a tipologia do habitat individual tentando conferir a cada pequena parcela a maior individualidade possível a mil e duzentas casas com um reduzido número de tipologias, dividindo os observadores sobre o efeito de monotonia ou de diversidade. Face a todas estas questões urbanas e arquitectónicas a Malagueira suscita uma avaliação socio-arquitectónica" ${ }^{1}$ ou, como diria Philippe Boudon "il fallait aller y voir"2.

\footnotetext{
${ }^{1}$ Este artigo reúne alguns resultados do projecto de investigação sobre o Bairro da Malagueira desenvolvido por Jean-Michel Léger (Coord.), Filipa Alvarenga e Gisela Matos. Este projecto foi financiado pela Fundação para a Ciência e Tecnologia (FCT) e pelo Plan Urbanisme Construction Architecture (PUCA). Para além de entrevistas a actores envolvidos na concepção da Malagueira, realizaram-se entrevistas a habitantes e efectuou-se o desenho das plantas actuais de dezanove casas a partir de um levantamento gráfico e fotográfico. Os autores gostariam de agradecer os especiais contributos e inestimáveis colaborações de: Nuno Portas, Isabel Guerra, Nuno Ribeiro Lopes, Alexandra Castro, Maria João Freitas, Manuela Oliveira, Carolina Leite, Roselyne de Villanova e last but not the least aos habitantes Malagueira.

2 Philippe Boudon quando interpelado pelas transformações dos habitantes às casas construídas em Pessac por Corbusier (Boudon, 1985: XI).
} 


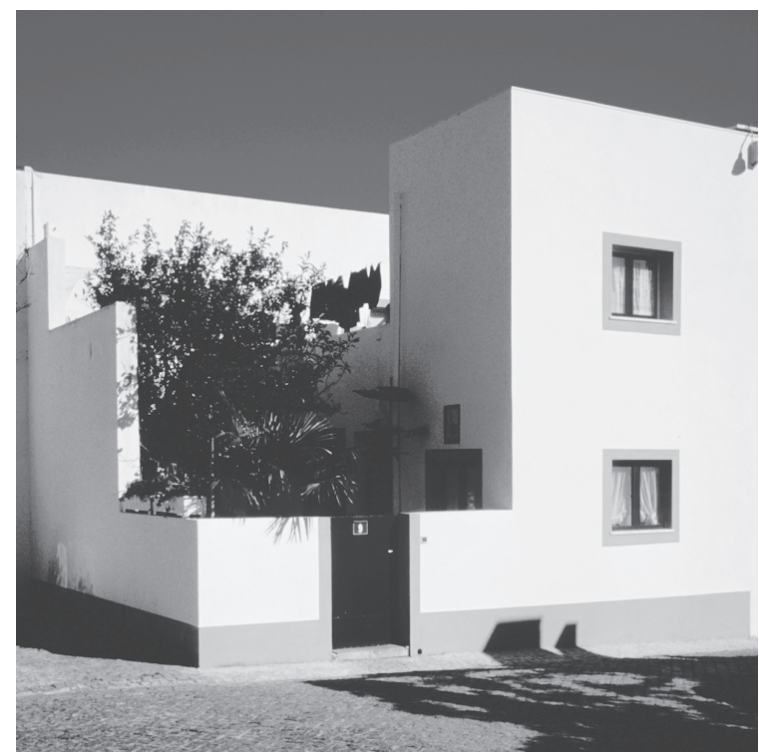

Casa de esquina com pátio de muro baixo (1,50 m). Foto de Jean-Michel Léger

\section{Malagueira, uma Aventura Política e Urbana}

\section{Siza, do Porto a Évora}

Siza Vieira notabilizou-se pela concepção, em Matosinhos, de um restaurante (1958-63), cujo longo telhado com inclinações cruzadas e acabamentos em madeira inspirados em Alvar Aalto, foi apontado, desde logo, como paradigma da inserção e integração da arquitectura no meio envolvente. Contudo, a confirmação da sua notoriedade internacional surge, curiosamente, graças a duas piscinas e duas agências bancárias, nomeadamente a de Oliveira de Azeméis (1958-65).

À semelhança de Alvar Aalto, Siza concebeu nos primeiros anos da sua carreira um grande número de casas privadas. Entre 1954 e 1976, contam-se pelo menos dezasseis projectos residenciais (apenas dois dos quais não foram concretizados) que proporcionaram a Siza experiência em termos de contacto directo com os clientes bem como a compreensão das suas necessidades.

Antes do 25 de Abril de 1974 Siza concebeu sob encomenda do Fundo de Fomento da Habitação (FFH) um programa de acesso à habitação no
Porto (Bairro do Bouça). Após o 25 de Abril foram realojados neste bairro indivíduos que viviam em barracas, sendo-lhes atribuídas casas no âmbito do SAAL $^{3}$ - Serviço de Ambulatório de Apoio Local criado em Agosto de 1974 pelo Secretário de Estado da Habitação e Urbanismo - Arq. ${ }^{\circ}$ Nuno Portas. Durante a vigência do SAAL foram constituídas cento e cinquenta cooperativas. Porém, dois anos e meio mais tarde, já sob o IV Governo, os projectos SAAL foram suspensos, bem como a maior parte do Programa de Habitação Social, à excepção da Malagueira, cuja construção, embora interrompida entre 1978-1980, foi concluída.

As associações apoiadas pelo SAAL não tendo carácter político, não foram protegidas por nenhum partido político: "Reacção clássica do aparelho de Estado centralista contra uma fórmula de gestão do alojamento que alterava todas as regras do alojamento estabelecidas. Face a esta rejeição generalizada aos projectos SAAL, por parte dos habitantes e do poder político, estes acabaram por desaparecer. Os habitantes ganharam alguns milhares de alojamentos e um conjunto de arquitectos, entre os quais Siza, conheceu a fama internacional com este programa que combina, de forma surpreendente, política, linguagem arquitectónica, participação das populações, recuperação de habitações degradadas, alternativas energéticas, diálogo entre o existente e o novo. Paradoxalmente, os arquitectos que preconizaram uma arquitectura branca e racionalista obtiveram os favores da crítica, enquanto que outros projectos mais populares e mais próximos do espírito SAAL foram completamente ignorados" $"$.

A complexidade da organização do conjunto habitacional do Bouça (Porto) serviu de modelo para as investigações sobre a tipologia efectuadas mais tarde para a Malagueira. Mas foi a forma inovadora, em termos de harmonização dinâmica do espaço construído (Frampton, 1986: 14), que fará realçar alguns anos mais tarde também no Porto, a reabilitação de S. Vítor, ambicioso e inconcluído projecto de Siza no âmbito do SAAL que acabou por ficar reduzido à construção de uma só fila de quinze casas de aspecto muito racionalista.

\footnotetext{
${ }^{3}$ Esta experiência, que vigorou até 1976 no âmbito de uma política de descentralização da gestão dos Programas de Habitação Social, pôs em prática o confronto entre os habitantes e os arquitectos na defesa de projectos residenciais negociados e participados.

4 Entrevista ao Arq. ${ }^{\circ}$ Nuno Portas a 10 de Dezembro de 1999.
} 


\section{Uma Coexistência de Populações Heterogéneas}

A Quinta da Malagueira é, assim, o terceiro projecto concebido por Siza Vieira no quadro das iniciativas SAAL. Em 1974 a capital do Alentejo transbordava intramuros na sequência do êxodo rural e da chegada de "repatriados" das antigas colónias, então tornadas independentes (Guerra, Fonseca Ferreira, 1990). Em 1975, com o objectivo de proceder ao ordenamento da periferia urbana de Évora, foram expropriados 27 hectares de uma exploração agrícola latifundiária designada Quinta da Malagueira, situados a menos de um quilómetro dos muros da cidade.

O Plano de Urbanismo elaborado em Lisboa pela Direcção-Geral do Ordenamento Urbano previa para a extensão ocidental de Évora uma divisão deste território em zonas de elevada, média e baixa densidade habitacional, sendo que a elevada densidade prevista para a Malagueira opôr-se-ia à baixa densidade de alguns bairros clandestinos já existentes. Em 1976 os habitantes formaram a Associação S. Sebastião, posterior ao processo SAAL, cujo responsável local, primeiro Presidente provisório da Câmara Municipal, decidiu criar uma associação com vista à construção de cem habitações, previstas para fora dos terrenos da Quinta da Malagueira. A partir da definição do local e da temática adoptada Nuno Portas e Jorge Silva (seu adjunto) escolhem em 1977 Siza Vieira para a realização do projecto urbanístico da Malagueira. A expe- riência reunida por este arquitecto desde 1975 nos projectos SAAL, sobretudo pelos resultados de um trabalho de experimentação em projectos participativos, realizados na cidade do Porto, e a recusa, por parte dos habitantes, do plano inicial que previa a implantação de várias casas cruciformes à semelhança das já existentes na zona Sul da Malagueira, justificou a escolha de Siza Vieira para a construção deste projecto que avança claramente com propostas inovadoras para a época, quer no plano urbano (as galerias de infra-estruturas - "aqueduto", a dimensão tipológica "aberta"), quer no plano arquitectónico (casas de desenho minimalista, geométrico e neoracionalista $)^{5}$.

Em 1978, a Câmara Municipal de Évora cedeu terrenos à Associação de moradores S. Sebastião e às Cooperativas Boa Vontade e Habitevora sugerindo-lhes que confiassem os seus projectos a Siza Vieira. Posteriormente, o Fundo de Fomento da Habitação (FFH) atribuiu um financiamento à Associação S. Sebastião para a construção de duas casas-tipo. Siza conseguiu desviar este financiamento para a realização dos alicerces para as primeiras cem casas, inicialmente previstas pelo SAAL para fora do bairro da Malagueira. Transferindo para a Malagueira a construção da primeira "tablete de chocolate" (a primeira grelha de casas), que concebeu e ofereceu gratuitamente, Siza pretendia criar uma dinâmica irreversível de construção e desenvolvimento do projecto. $\mathrm{O}$ apoio das cooperativas manteve-se nos anos seguintes: a Cooperativa

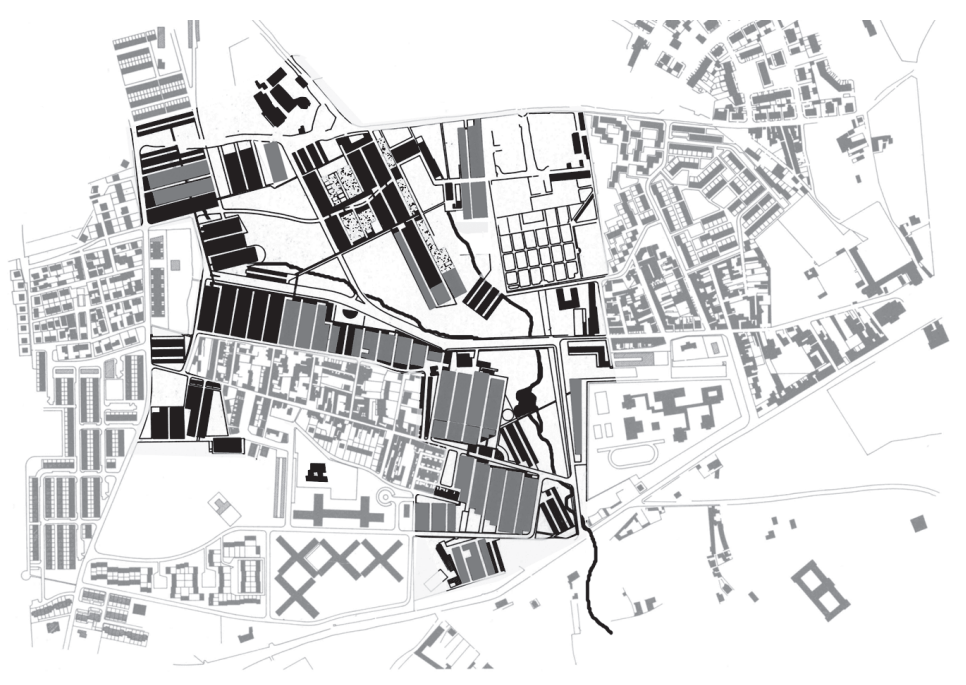

\begin{tabular}{|l|}
\hline Cooperativas \\
Habitação Social \\
IGHAPE \\
Lotes Privados
\end{tabular}

Plano da Malagueira segundo os três tipos de estatuto de ocupação: Cooperativas, Habitação Social IGHAPE, Lotes Privados

Fonte: José P. Duarte, $1999^{6}$

\footnotetext{
5 Sobre o historial da Malagueira, ver nomeadamente Rayon, 1987; Molteni, 1997; Collovà, 1999; Siza, 2000.

${ }^{6}$ Para uma apresentação completa da evolução do bairro, das diferentes tipologias e para uma análise mais pormenorizada da gramática criadora destas tipologias, consulte o extraordinário site criado por José P. Duarte em 1999 na sequência do seu Doutoramento: www.civil.ist.utl.pt/ jduarte/malag/
} 
Giraldo (decorrente da Associação S. Sebastião) construiu 200 casas; a Cooperativa Boa Vontade, 400; a Habitevora (ela própria nascida da Cooperativa Boa Vontade), 52. No total, as cooperativas construíram 652 casas e o FFH 418. Os restantes lotes, cerca de uma centena, foram vendidos a particulares que apresentaram o seu projecto na base de um plano-tipo elaborado por Siza.

Os habitantes da Malagueira confirmam que são as relações criadas pelo trabalho e pelos filhos que fomentam e aprofundam as relações de vizinhança (Fonseca Ferreira, Guerra, Costa Pinto, 1990), às quais acrescentam outro vector, o das trocas derivadas da realização de obras e transformações a partir de uma solidariedade entre habitantes cujas casas sofreram ou apresentam defeitos e anomalias de construção comuns.

A existência desta "mistura social" na Malagueira, deve-se tanto às circunstâncias da sua programação, como à vontade planeadora do arquitecto. Apesar do forte contraste entre a primeira "tablete de chocolate" do bairro - o pequeno bairro "nobre" dos primeiros habitantes - e o "enclave" onde se encontram muitos indivíduos de etnia cigana, a "mistura social" é real graças à interpenetração dos programas privados e públicos, não somente à escala da Malagueira, mas à escala dos seus subconjuntos $\mathrm{e}$, às vezes, mesmo das ruas. Na parte norte e noroeste do bairro, por exemplo, num ou noutro lado da mesma rua, casas construídas sobre um lote privado ou pela Cooperativa Giraldo estão em frente de casas de habitação social do IGHAPE.

É impressionante, todavia, o abandono em que se encontra o "enclave" onde residem os ciganos, abandono este sobretudo da responsabilidade do gestor dos alojamentos mas também dos serviços municipais responsáveis pela gestão dos espaços públicos do bairro. Segundo Alexandra Castro, que efectuou uma pesquisa sobre esta população, a situação parece ter piorado nos últimos anos (Castro, 1995). Os ciganos foram realojados na proximidade dos locais onde tinham as suas barracas, e, tendo em conta que o uso de um alojamento sedentário não se opõe à continuação das práticas itinerantes, A. Castro observou na Malagueira uma ocupação e apropriação do espaço público contíguo às suas casas característico de práticas associadas ao modo de vida itinerante: ocupação do espaço exterior para cozinhar, lavar a louça e roupa, realização de jogos, festas e discussões. Estas formas de ocupação do espaço reforçaram a autonomização do "território cigano", que parece actualmente interdito a "Gadjés".
A Malagueira é um bairro residencial periférico essencialmente monofuncional, dotado apenas de alguns comércios, cafés e restaurantes. O supermercado, as escolas primárias e secundárias e a piscina municipal estão localizados à volta dos limites do bairro, mas não intervêm directamente na sua animação. Todos esperam com expectativa a construção da "Cúpula", lugar público semicoberto, destinado a centro cívico e comercial, que deveria constituir a nova centralidade do bairro. Para além da Cúpula, Siza projectou e concebeu uma clínica, um hotel residencial (desenhado como uma caravançarai) e um restaurante com vista panorâmica. Para a construção destes dois últimos equipamentos faltam "apenas" investidores. Já a realização da Cúpula pressupõe que a vontade política municipal de concluir o Projecto seja tão forte como o foi durante todo o longo mandato do Presidente comunista da Câmara Municipal, Abílio Fernandes (1976-2001).

A Malagueira foi desde o momento da sua construção um instrumento de luta política entre o PCP e o PS, mas também originou divisões entre arquitectos e engenheiros, entre administração central e eleitos locais. Expressão de um racionalismo assente em propostas inovadoras, foi ao encontro das maneiras de pensar e fazer dos funcionários e dos interesses dos arquitectos locais. O Engenheiro-Chefe dos serviços técnicos era hostil ao projecto e as próprias cooperativas não confiavam na fiabilidade do sistema construtivo, sobre o qual até o próprio LNEC levantava dúvidas. Normalmente as infra-estruturas são da responsabilidade das Câmaras Municipais. Porém, a de Évora recusava-se a pagar o custo adicional dos aquedutos, custo este mais tarde suportado pelo Estado. O projecto beneficiou ainda do apoio do GAT (Gabinete de Apoio Técnico), serviço técnico descentralizado colocado à disposição dos pequenos municípios, dotados de recursos insuficientes para organizar sozinhos o seu planeamento urbano.

\section{Experimentações Múltiplas}

A concepção da Malagueira foi guiada por três intenções, que representaram sob muitos aspectos experimentações: a construção de casas costas com costas ao longo de galerias de infra-estruturas (o "aqueduto"); a adaptação de uma grelha urbana à topografia local; a tipologia evolutiva das casas, ela própria assente em inovações técnicas. 


\section{O aqueduto}

O termo de "aqueduto", utilizado por Siza como referência ao aqueduto de Évora que data do século XVI, designa efectivamente uma galeria técnica, à qual os habitantes e técnicos chamam também "conduta". O aqueduto é a espinha dorsal da construção costas com costas das casas, formando também a infra-estrutura necessária para a distribuição de água, electricidade, telefone e televisão (a única excepção é o gás). Destaca-se, igualmente, pela posição elevada que ocupa, como uma superstrutura bem visível do bairro. Para Siza, esta visibilidade tem um duplo significado: a ligação do bairro novo à cidade de Évora e a unificação dos diferentes territórios da Malagueira. Em detrimento da construção de uma clássica rede subterrânea, o aqueduto, ainda que mais caro, devia facilitar as intervenções ulteriores de manutenção. Porém, nem sempre é fácil o acesso, em particular pelas companhias de telefone ou televisão, e as suas galerias mais altas tiveram mesmo que ser fecha-

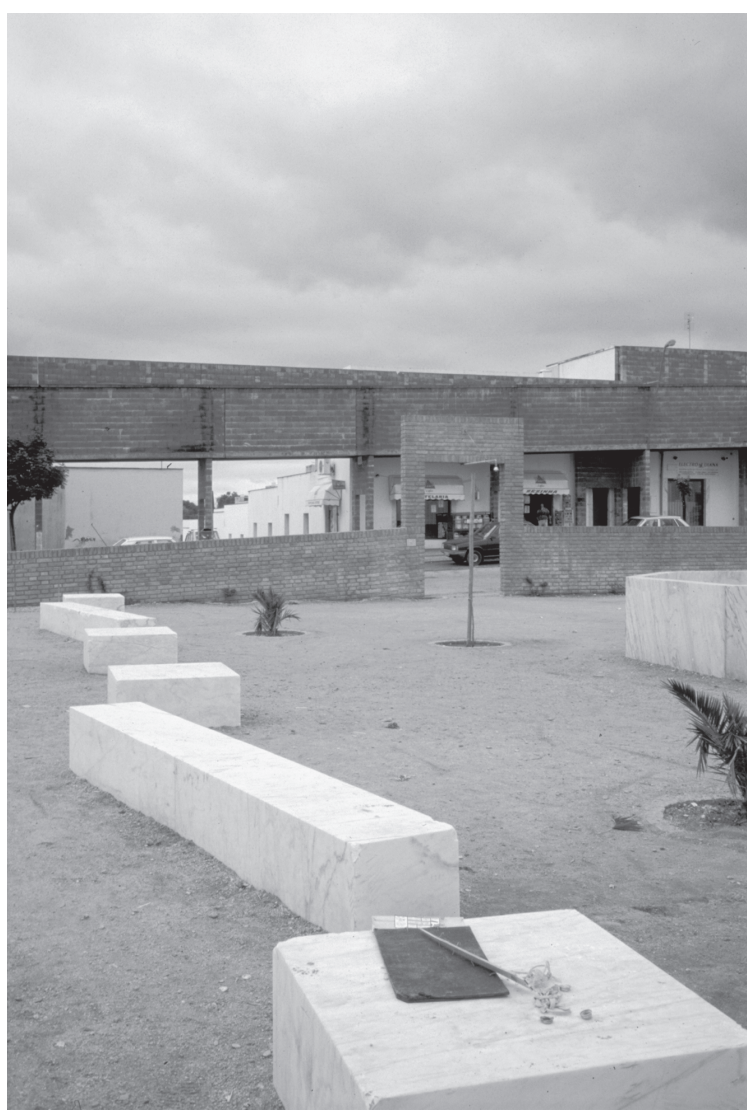

Bancos de mármore no parque público central. Ao fundo, o aqueduto.

Foto de Jean-Michel Léger das devido ao tráfico de droga e frequentes assaltos a casas.

O debate a favor ou contra o aqueduto ultrapassa largamente o que diz respeito à aparência dos seus acabamentos, que a maioria dos habitantes gostaria de ver revestido ou pintado de branco, já que Siza o concebeu no local destinado a acolher a futura Cúpula, onde o aqueduto estabelece com arcadas monumentais uma porta do bairro. A sua construção em blocos de betão é justificada pelo elevado preço dos tijolos pequenos maciços. Porém, os argumentos a favor desta "pobreza intencional" ("o dinheiro é para as casas, não para as redes - viária, eléctrica, etc."), da sua funcionalidade e do seu simbolismo são partilhados apenas pelos habitantes mais identificados com o projecto de Siza.

$\mathrm{O}$ aqueduto é o fio condutor que une todas as peças deste grande território de 27 hectares. $\mathrm{O}$ grau zero da arquitectura urbana deveria, no entanto, confiar essa função ao espaço público (ruas, praças, parque) sem recorrer a uma tal superstrutura, com uma eficácia racional contestável e uma eficácia simbólica discutível. Contudo, Siza não concebeu um sistema: de facto, não o voltamos a encontrar noutro grande projecto comparável como o de Haia, na Holanda (Schilderswijk, 1985-1988 e Doedijnstraat, 1989-1993). Grosseiramente construído e mal recebido pela crítica, assim como pelos habitantes, o aqueduto foi, se assim se pode dizer, "enterrado", apesar da pertinência e virtualidade do conceito. O que poderia ter-se tornado num tema arquitectónico permanece um protótipo experimental, o que reforça ainda mais a singularidade da Malagueira.

\section{Uma Morfologia Integrada na Paisagem}

Existem várias referências da Malagueira: casas em banda de Oud na Holanda, Siedlungen de Frankfurt, Berlim, Zurique ou Berna, projecto "Roq e Rob" de Corbusier, parcelas de 8 por $8 \mathrm{~m}$ de Ecochard em Casablanca, etc. A estes exemplos acrescenta-se o de Peter Testa, com o plano das colónias gregas retomado pelos Romanos, no qual os grandes rectângulos das ruas principais são recortados por ruas secundárias que delimitam insulae alinhados costas com costas (Testa, 1984). A proposta de Testa é ainda mais interessante quando constatamos a origem romana de Évora e a von- 
tade de Siza de inscrever o seu plano de cidade nova na história e geografia do lugar.

$\mathrm{Na}$ Malagueira a morfologia do bairro e a tipologia da habitação estão estreitamente relacionadas. Para conseguir nos 27 hectares da Malagueira uma densidade equivalente à das habitações colectivas previstas pelo plano de urbanismo elaborado da Direcção-Geral de Ordenamento Urbano, reservando simultaneamente metade do terreno para um vasto parque público, Siza teve de reduzir a dimensão das parcelas (8 por $12 \mathrm{~m}$ ) e a largura das ruas, medindo as mais estreitas entre 4 a 6 metros apenas. As ruas secundárias inicialmente concebidas para os peões numa altura em que não haviam muitos automóveis, tiveram que progressivamente ser adaptadas ao trânsito automóvel. Em certas ruas os moradores chegaram mesmo a organizar-se no sentido de determinar consensualmente um único lado de estacionamento com vista a facilitar a circulação já que a construção de garagens não conseguiu acompanhar a expansão do parque automóvel. Mas, na verdade, a maior parte das garagens é utilizada como local de arrumações secundário uma vez que há pouco espaço disponível nas casas.

Na Malagueira a harmonização dinâmica entre o espaço construído e as formas criadas pela natureza caracteriza-se por ter em conta, por um lado, os caminhos existentes, os acidentes de relevo, as rochas, o lago, as árvores e, por outro, por estabelecer uma ligação com o já existente Bairro de Santa Maria. Por exemplo, tanto de uma parte como de outra da Praça Manuel Carlos, o tratamento dos ângulos, a volumetria média das casas, a alternância de espaços públicos (os jardins) e privados (as casas) parecem tanto comuns à autoconstrução de Santa Maria como à construção arquitectónica de Siza Vieira. Em contrapartida, sobre a longa Rua dos Dois Bairros, o padrão da implantação das casas obriga a que estas exponham a Santa Maria os seus muros laterais, sem portas ou janelas.

Os desenhos à mão de Siza testemunham a importância conceptual do projecto paisagístico (Molteni, 1997). Foi a ausência de financiamento que prolongou longamente o ordenamento dos espaços públicos, de onde resultou a imagem de bairro não acabado durante mais de quinze anos e o sentimento de que os espaços verdes são residuais embora tenham sido projectados por Siza como o pulmão do bairro.

O ordenamento dos espaços verdes realizado durante os anos 90 está na origem da diferença existente entre a parte inferior e a parte superior da Malagueira. Na parte inferior e ao centro, a relva densa, plantações abundantes e o pequeno lago compõem uma paisagem desenhada de acordo com o modelo anglo-saxónico, pouco adaptado, porém, às condições climatéricas do Alentejo, apesar da manutenção do parque ser bastante cuidada pelos serviços municipais. A parte superior, o bairro socialmente mais pobre, está construído sobre um terreno naturalmente mais seco, ao ponto que mal se distingue a vegetação selvagem da cultivada ou o pousio das antigas terras agrícolas, segundo uma ambiguidade paisagista que não é, ela própria, desprovida de poesia.

As qualidades contraditórias do espaço público - os espaços "de sociabilidades frias e de relações frágeis, de distância na co-presença" (Joseph 1995: 12), de rituais de exposição e de ocultação, de circulação e de comunicação - fazem com que os espaços verdes, as ruas e as praças sejam objecto de procuras contraditórias, uma vez que cada utente-morador espera que respondam às suas próprias práticas específicas: simples travessia, passeio familiar, jogging, jogos de futebol, encontros com vizinhos, etc. Os espaços públicos e verdes da Malagueira não escapam à sorte de todos os seus congéneres, como a insegurança, real ou aparente, ou o embaraço face a dejectos caninos, passando por actos de vandalismo (Castro, 2002).

\section{Tipologias Evolutivas}

Monotonia ou diversidade? O artigo que Maria Filomena Mónica dedicou à Malagueira, num semanário, destaca os sentimentos de "tristeza surda", "angústia" e "ambiente opressivo" frequentemente sentidos pelos visitantes mais apressados (Mónica 1998: 28). Siza, que lamenta que "a sociedade de consumo que afecta a cultura urbana nos obriga a uma construção artificial da diferença" (Zaera 1994: 17-18), não recusa a monotonia quando ela significa a regularidade de uma ordem urbana e a igualdade democrática. 

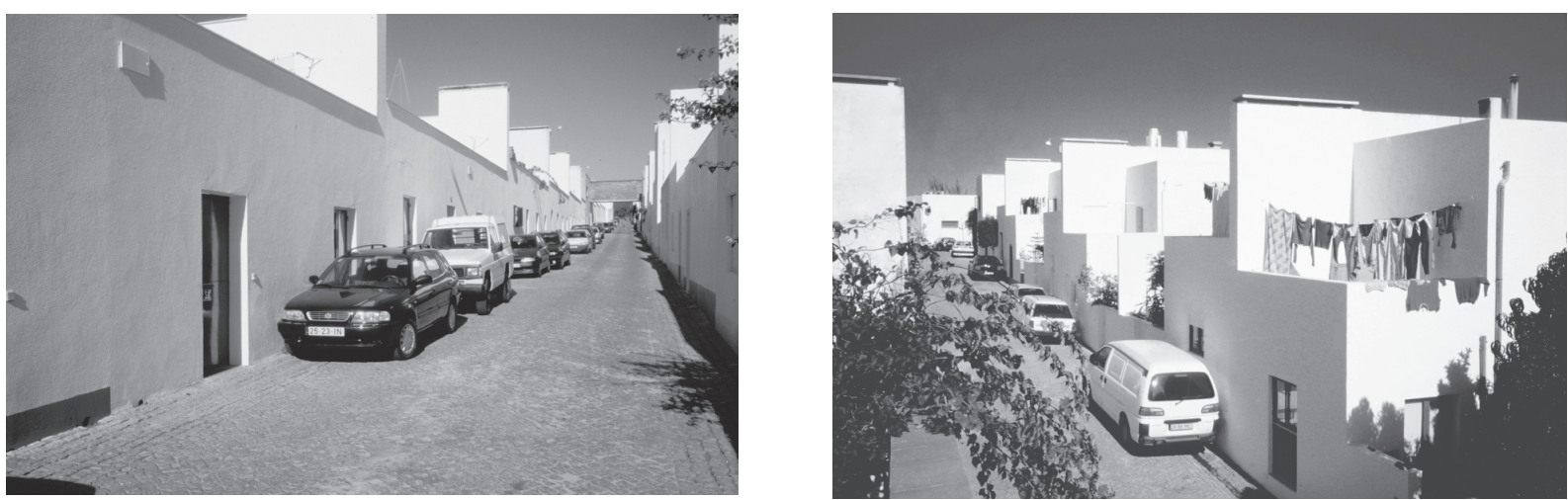

Casas de habitação social IGHAPE: muros altos $(3,50 \mathrm{~m})$ e rua mais "urbana"; Casas de cooperativa: percepção da diversidade criada pela forma das chaminés, dos terraços e dos pátios com muro baixo.

Fotos de Jean-Michel Léger

Em 1977 foram publicadas as duas principais tipologias evolutivas: o tipo $\mathrm{A}$, com pátio à frente $\mathrm{e}$ o tipo B, com pátio atrás, variando do T2 ao T5 sobre uma mesma parcela de 8 por $12 \mathrm{~m}$. No entanto, somente nove casas de tipo B foram construídas por uma das cooperativas, pois a tipologia de pátio à frente reuniu a preferência generalizada tanto das cooperativas como do IGHAPE.

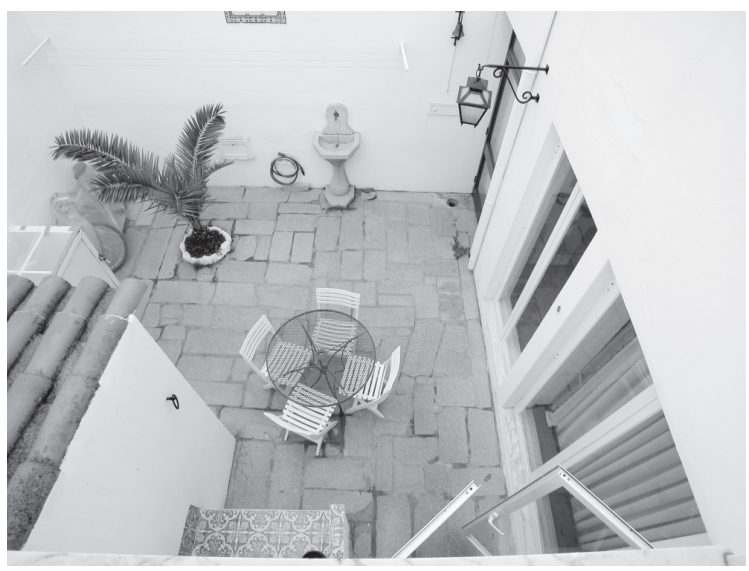

Casa de tipo Bb com pátio atrás.

Foto de Jean-Michel Léger

Outras tipologias vieram, posteriormente, enriquecer o catálogo inicial (por exemplo, parcelas de 7 por $12 \mathrm{~m}$ e 6 por $12 \mathrm{~m}$ ), contando-se actualmente com trinta e três tipos e subtipos de casas, sem introduzir a variação da altura do muro do pátio à frente, que teoricamente multiplica por três a possibilidade de diferenciação das casas. Por con- seguinte, no total, não há menos de uma centena de planos e de desenhos de fachadas diferentes, sem contar com as modificações, mais ou menos autorizadas que, deste a construção de uma escada exterior entre o pátio e o terraço à personalização das portas e das janelas, aumentam ainda mais a diversidade das casas, tal como é percepcionada pelos habitantes e pelos visitantes.

Quadro n. ${ }^{0}$ 1- Principais tipologias das casas da Malagueira

\begin{tabular}{|l|c|c|c|c|c|c|}
\hline Tipologia & T1 & T2 & T3 & T4 & T5 & Total \\
\hline Ab & & 25 & 334 & 29 & 30 & 418 \\
\hline Ac & & 88 & 80 & 29 & 27 & 224 \\
\hline Ad & & & & 1 & & 1 \\
\hline Ae & & & 1 & & & 1 \\
\hline Bb & & & 5 & 2 & 2 & 9 \\
\hline Ca & & 1 & 149 & 32 & 8 & 190 \\
\hline Cb & & & 1 & 9 & 1 & 11 \\
\hline Da & & 15 & 134 & 9 & 1 & 159 \\
\hline Db & & & & 7 & & 7 \\
\hline E & & 1 & & & & 1 \\
\hline F & 6 & & & & & 6 \\
\hline P1 & & & 7 & & & 7 \\
\hline P2 & & & 28 & 6 & & 34 \\
\hline X & & & 10 & 5 & & 15 \\
\hline Y & & & 20 & & & 20 \\
\hline Total & 6 & 130 & 769 & 129 & 69 & 1103 \\
\hline
\end{tabular}

Fonte: de acordo com a classificação estabelecida por José P. Duarte ${ }^{7}$ e completado pelos autores deste projecto.

\footnotetext{
${ }^{7}$ www.civil.ist.utl.pt/ jduarte/malag/
} 

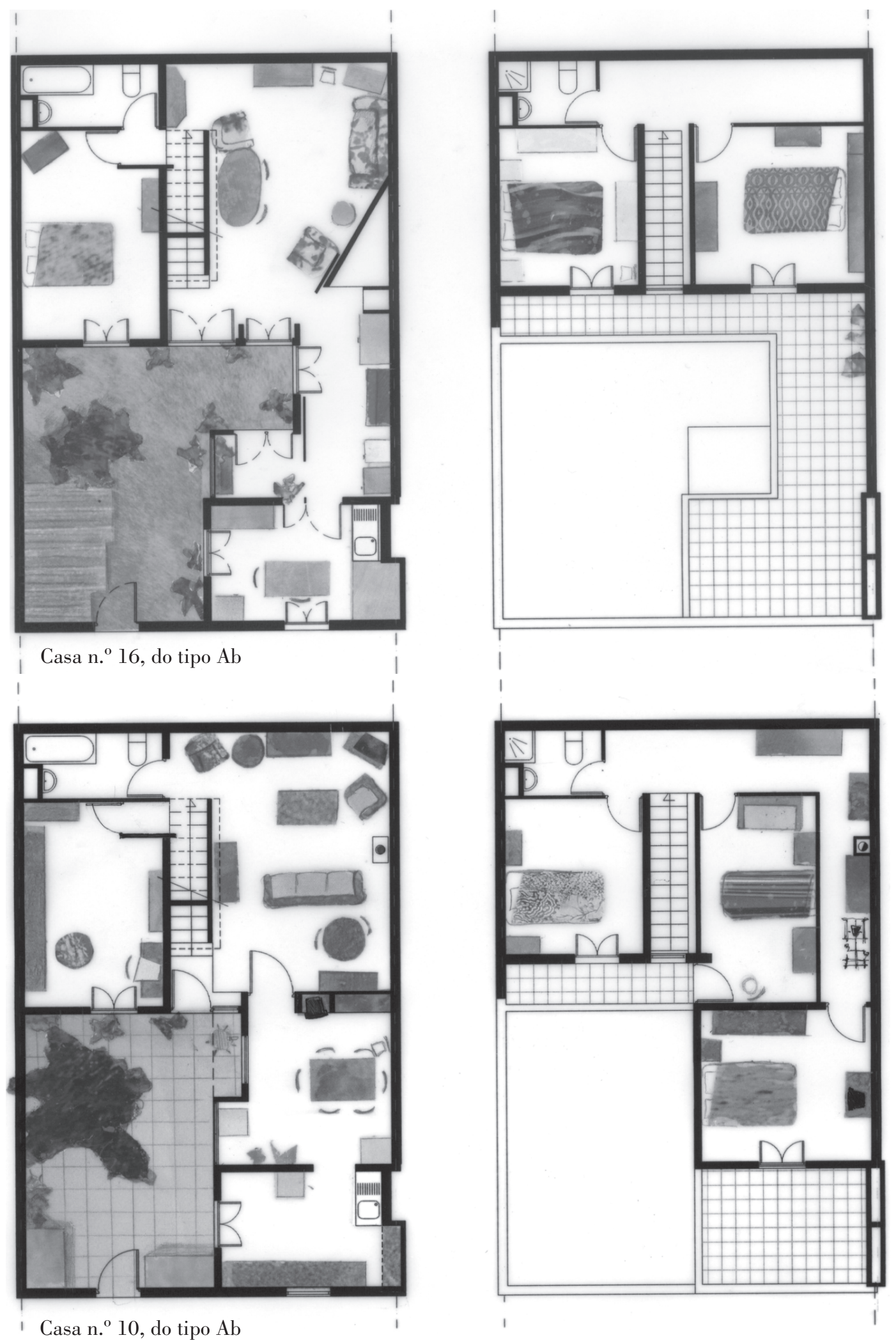

Comparação entre duas casas de tipo $\mathrm{Ab}$ (casa n. ${ }^{\circ} 16$ e casa n. $\left.{ }^{\circ} 10\right)$. Casa não transformada de um arrendatário do IGHAPE (casa n. ${ }^{\circ}$ 16) e casa transformada de uma família proprietária (casa n. $\left.{ }^{\circ} 10\right)$. A ampliação da sala de jantar (entre a cozinha e a sala de estar) permite colocar mais convenientemente uma mesa enquanto que a supressão do pequeno e triangular espaço de arrumos dá à sala de estar uma forma quadrada mais confortável. A supressão da lavandaria faz contudo perder a subtileza original da interpenetração entre a casa e o pátio. 

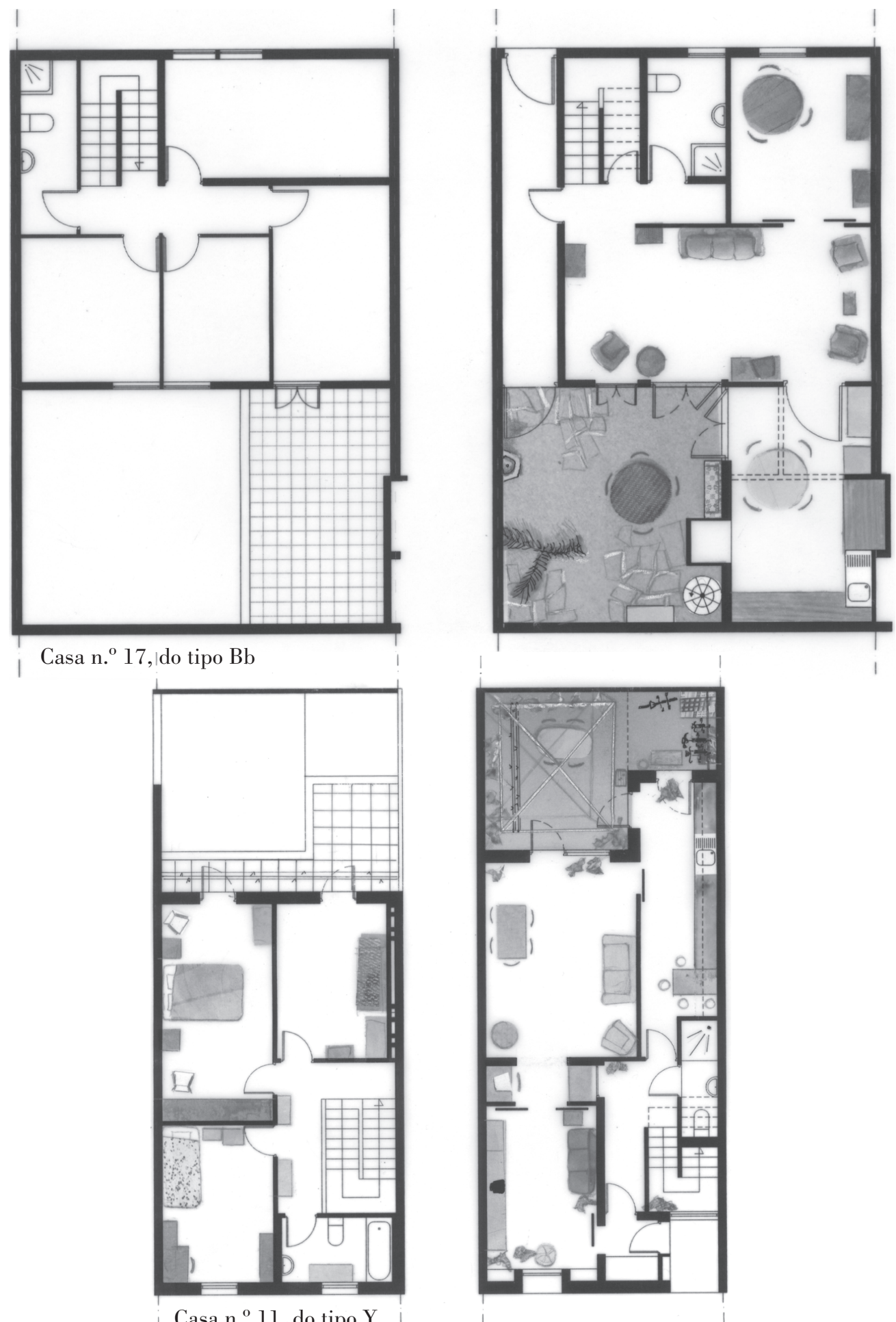

Casa n. ${ }^{\circ} 11$, do tipo $\mathrm{Y}$

Comparação de dois tipos de casa com pátio atrás (casa n. ${ }^{\circ} 17$ e casa n. ${ }^{\circ} 11$ ). Na casa n. ${ }^{\circ}$ 17, de tipo Bb, a supressão das divisões originais e a utilização de uma quarto como sala de jantar conferem ao conjunto cozinha sala de estar - sala de jantar uma área total de 46,50 $\mathrm{m}^{2}$. Ligeiramente mais pequeno que o pátio à frente das casas de tipo $\mathrm{Ab}\left(23 \mathrm{~m}^{2}\right.$ contra $\left.26 \mathrm{~m}^{2}\right)$, o pátio atrás está mais protegido. No novo tipo Y (1997) de pátio atrás, a economia do espaço faz perder $6 \mathrm{~m}^{2}$ à parcela, que mede 6 por $15 \mathrm{~m}$, enquanto que, anteriormente, todas as casas da Malagueira eram construídas sobre uma parcela de 8 por $12 \mathrm{~m}$. O pátio, reduzido a $14 \mathrm{~m}^{2}$, fica mais sombrio e, em relação às casas $\mathrm{Bb}$, deixa de ter o corredor que nos conduz da entrada ao pátio. Em contrapartida, o hall de entrada e o pequeno corredor asseguram uma boa intimidade às divisões do rés-do-chão. 

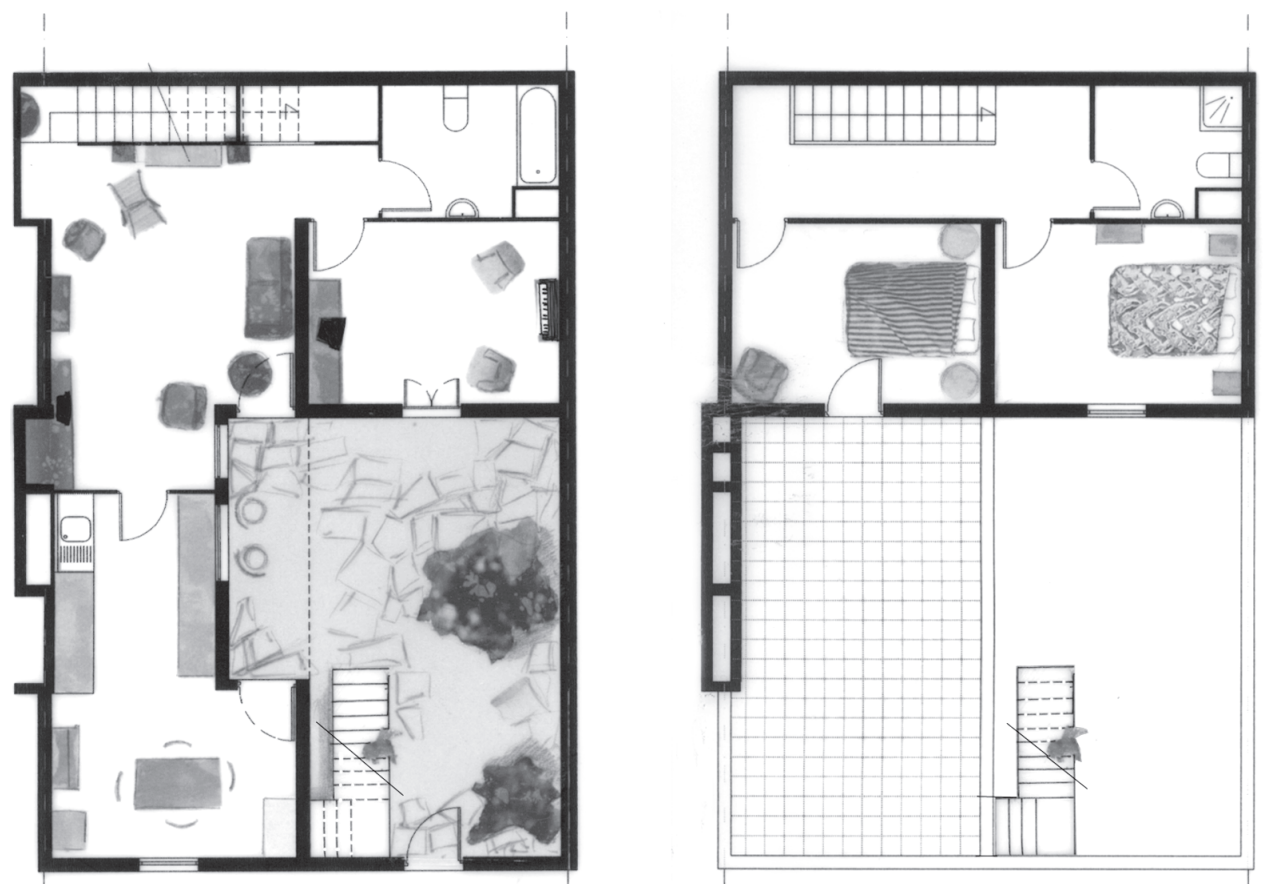

| Casa n. ${ }^{\circ} 3$, do tipo Ca
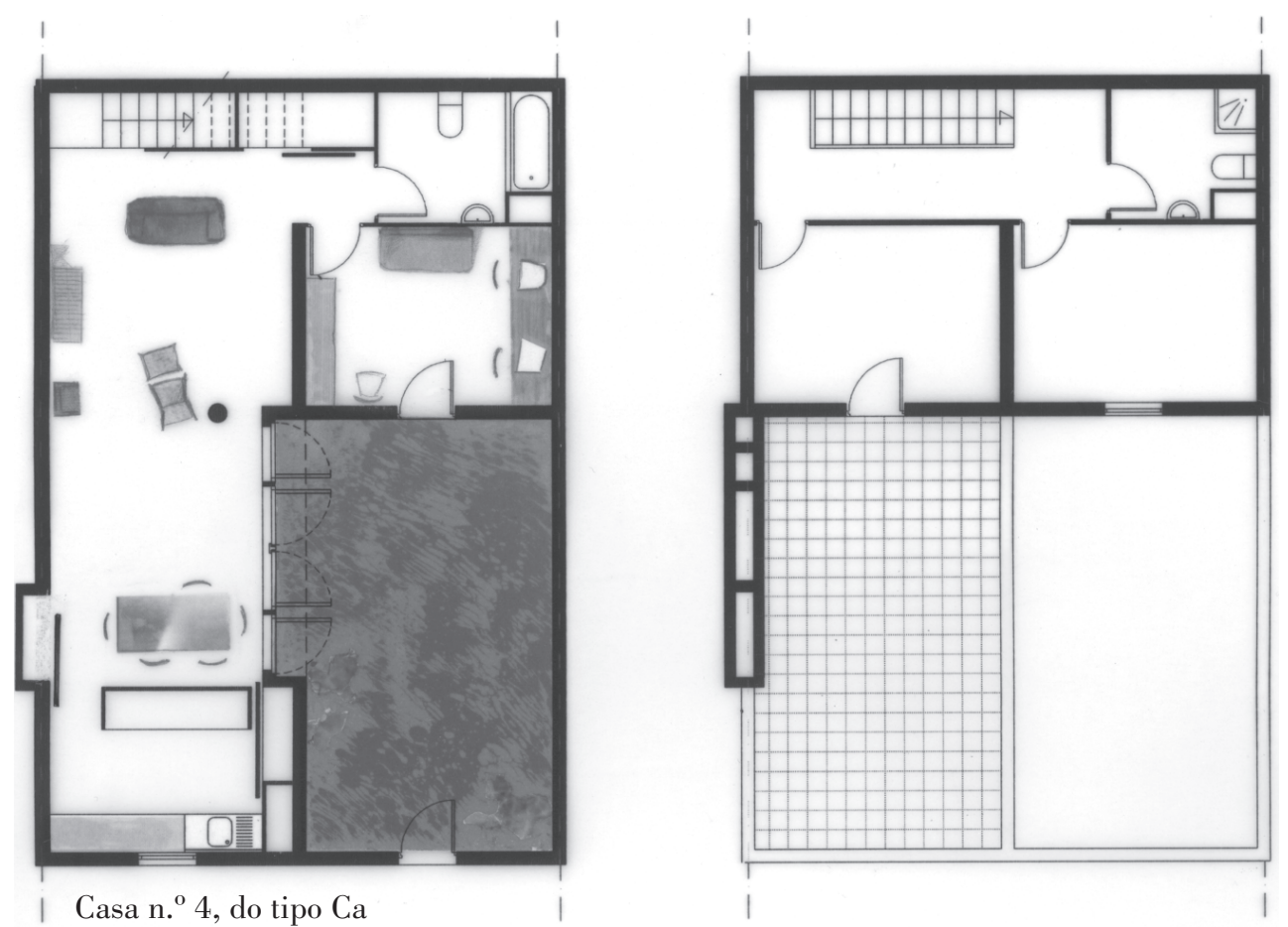

Comparação das transformações de duas casas de tipo Ca (casa n. ${ }^{\circ} 3$ e casa n. $\left.{ }^{\circ} 4\right)$. Na casa n. $^{\circ} 3$ os habitantes inverteram a disposição a cozinha e a sala de jantar originais, de maneira a terem uma sala de jantar maior, com o preço do seu afastamento da sala de estar. A colocação de uma escada exterior permite ligar o pátio ao terraço. Já os novos residentes da casa n. ${ }^{\circ} 4$, preferiram conservar a posição original da sala de jantar e manter a continuidade entre esta e a sala de estar. No entanto, à semelhança de alguns habitantes das casas de tipo Ab, alargaram-na sobre o pátio, que, no tipo Ca, é maior (30,3 m2 contra 26,2 m2 no tipo $\mathrm{Ab}$ ). Aqui, a grande parede envidraçada que dá para o pátio estabelece uma outra continuidade entre a casa e o pátio protegido por um muro alto de $3,50 \mathrm{~m}$. 
A transformação da construção original, no momento das obras ou posteriormente, exprime as mais tangíveis manifestações da apropriação do espaço habitacional. As modificações e transformações introduzidas pelos habitantes ao plano inicial são relativamente regulares, a saber:

- Colocação de uma escada exterior de acesso directo ao terraço, com vista a mais facilmente estender a roupa que se pretende secar, passando pelo pátio (onde frequentemente é colocado um tanque) ou desde a cozinha ou da casa de banho do rés-do-chão, onde a máquina de lavar roupa está instalada. Faz-se, assim, de forma mais prática e espaçosa, o percurso entre o terraço e o pátio, que correspondem a uma oposição entre os espaços de desordem (pátio e terraço) e de ordem (interior).

- Supressão do pequeno e pouco prático espaço triangular de arrumos localizado na sala de estar. As arrumações encontram-se, assim, repartidas pelos corredores, quartos (sobretudo quando um deles serve apenas de escritório ou quarto de visitas) ou ainda na garagem situada no exterior (e às vezes bastante afastada) da casa;

- Alargamento da sala de jantar nas casas de tipo $\mathrm{Ab}$, de longe as mais numerosas (418 exemplares). Posicionada entre a cozinha e a sala de estar, a sua forma estreita manifesta a elegância do desenho de Siza conferindo simultaneamente ao pátio uma forma em $\mathrm{L}$ onde o lado pequeno, penetrando na casa, desenvolve uma interessante frente de vidro, que multiplica o número de portas-janelas. Porém, a sala de jantar

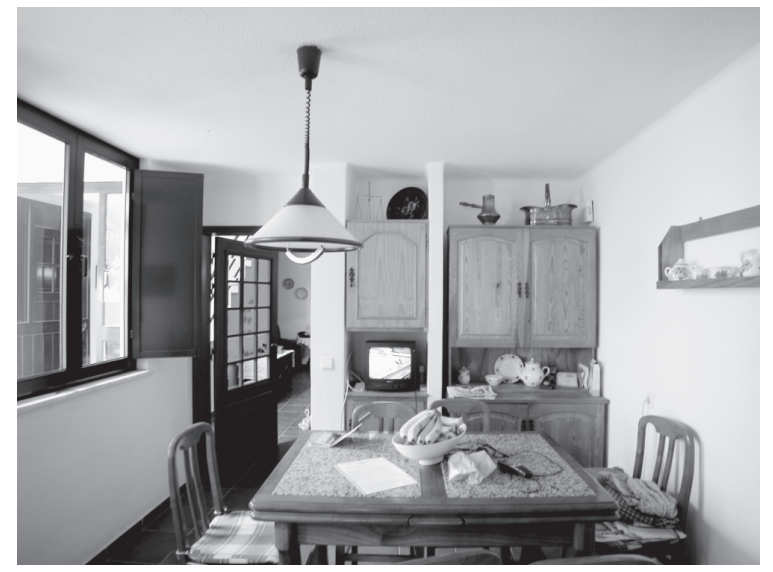

Sala de jantar ampliada, numa casa de tipo Ab (casa n. ${ }^{\circ} 10$ ).

Fotos de Jean-Michel Léger é alargada de maneira a poder colocar-se a mesa perpendicularmente à parede. Esta alteração contribui para uma maior fluidez do espaço interno, mas à custa da supressão da lavandaria e da transição entre o exterior e o interior que ela representava. A ampliação do conjunto cozinha-sala de jantar, realizada por razões de espaço útil, simplifica, por conseguinte, a organização original do espaço sacrificando uma hierarquia de transições pouco adaptada à pequena dimensão das casas. O "savoir faire" arquitectónico de Siza desenvolvido nos seus trabalhos anteriores em grandes casas cede, desta forma, perante as necessidades imperiosas da ampliação do espaço útil da casa.

- A ampliação da casa, antecipada por Siza, através da concepção da tipologia evolutiva: os quartos adicionados a posteriori são ganhos sobre a área do terraço, ou seja, os quartos do T3, T4 e T5 conseguem-se sobre o terraço do T2.

- Por último, ou antes em primeiro lugar, obras que visam reparar defeitos ou anomalias de construção associadas a algumas inovações técnicas do projecto, nomeadamente no que respeita à cobertura do terraço.

As casas em banda construídas pelas cooperativas são uma tipologia muito difundida, tal como as casas isoladas sobre uma só parcela, se bem que os habitantes tenham a "competência" de uma como de outra. As casas com o pátio fechado (muro alto) da Malagueira assemelham-se ao tipo de casa urbana vulgarmente mais aceite pelos habitantes dos estratos sociais mais elevados, que pretendem

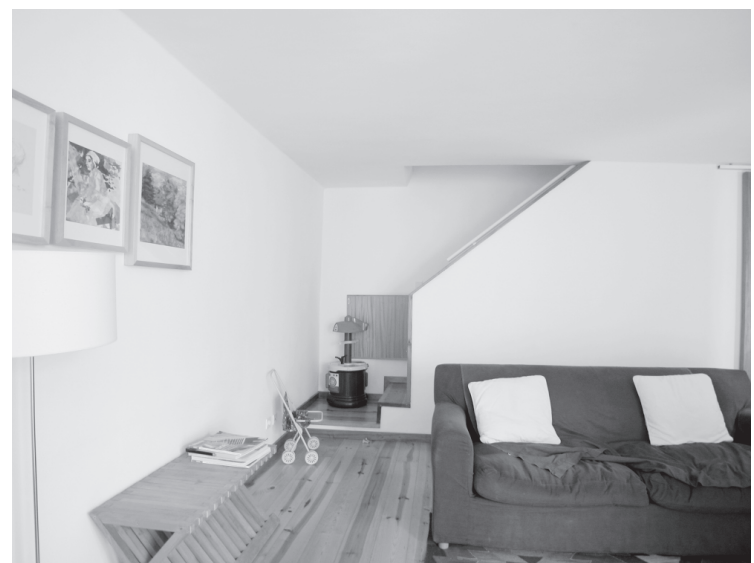

Sala de estar ampliada numa casa de tipo Ca (casa n. ${ }^{\circ}$ ).

\footnotetext{
${ }^{8}$ Conforme Henri Raymond (1984).
} 
identificar a Malagueira às casas antigas de Évora, enquanto que para os habitantes de cultura mais popular a "verdadeira" casa é aquela que está rodeada de um jardim.

\section{O muro, é o pátio; o pátio, é a casa}

Siza tinha inicialmente projectado para o muro da frente do pátio, uma altura de $3,50 \mathrm{~m}$, antes de propor a pedido das cooperativas, duas outras alturas, de 2,25 m e 1,50 m, respectivamente. Poucos habitantes puderam escolher a altura do muro, quer porque enquanto arrendatários de habitação social do IGHAPE o seu muro era exclusivamente de 3,50 m (todas as casas do IGHAPE foram construídas desta forma), quer porque compraram uma casa com uma altura de muro já estabelecida. Assim, a "preferência" expressa pelos habitantes não pode assentar na sua experiência face a estas três diferentes alturas de muro.

No entanto, contrariamente às nossas hipóteses iniciais, segundo as quais o muro mais alto tinha a preferência dos arquitectos, mas não a dos habitantes influenciados pelo modelo das moradias das periferias, concluímos que este muro mais alto pode ser igualmente preferido pelos habitantes. Com efeito, o muro alto assegura um conforto climático superior, maior intimidade e um sentimento de maior segurança. Dada a estreiteza das ruas e pátio, o muro baixo expõe a casa ao exterior, pondo-a a descoberto e aumentando, assim, o sentimento de vulnerabilidade, enquanto que o fechamento proporcionado pelo muro alto, produz em contrapartida o sentimento de maior protecção. O pátio pode então ser vivido como uma verdadeira divisão da casa, mas a céu aberto, enquanto que pátio com o muro baixo é mais um jardim fronteiro à casa ou um simples espaço cimentado orientado para a rua. É por esta razão que, após alguns anos, os habitantes proprietários revêem a sua percepção inicial sobre o pátio e a altura do muro e acabam, geralmente, por subi-lo.

Os significados em torno da altura do muro são também corrigidos por um processo de distinção, que encontra a sua origem nos primeiros debates entre Siza e as cooperativas. Os habitantes com maiores qualificações académicas (arquitectos, mas também engenheiros, técnicos, professores, educadores, etc.) distanciam-se dos gostos populares e pequeno-burgueses e apoiam-se na escolha de Siza, considerando o muro elevado como mais eficaz contra a expressão da individualidade, ou seja ao privilegiar a intimidade não deixa revelar nada da identidade do seu proprietário, enquanto que, com o muro baixo, o pátio e a casa são necessariamente expostos (Haumont, Raymond, 2000). Esconder-se por detrás do muro elevado, é proteger-se por detrás do espaço público da rua, em oposição às práticas privadas populares que mostram os anões de jardim ou os churrascos como em qualquer bairro de moradias (Castro, 1998), começar por exemplo no contíguo bairro "clandestino" de Santa Maria. No entanto, pondo a descoberto o pátio e a casa, favorecendo as plantações e uma decoração necessariamente voltada também para a rua, o muro baixo implica mais comunicação e trocas com o exterior. Seria necessário prosseguir a pesquisa para aferir as nossas observações sobre os modos de sociabilidade induzidos pela altura do muro. Os habitantes adeptos do muro alto parecem querer ser os garantes da boa urbanidade, a invisibilidade das práticas individuais atrás dos muros altos é um meio de garantir a respeitabilidade do bairro. Foi por conhecer efectivamente o seu mundo que Siza preferiu o muro alto.

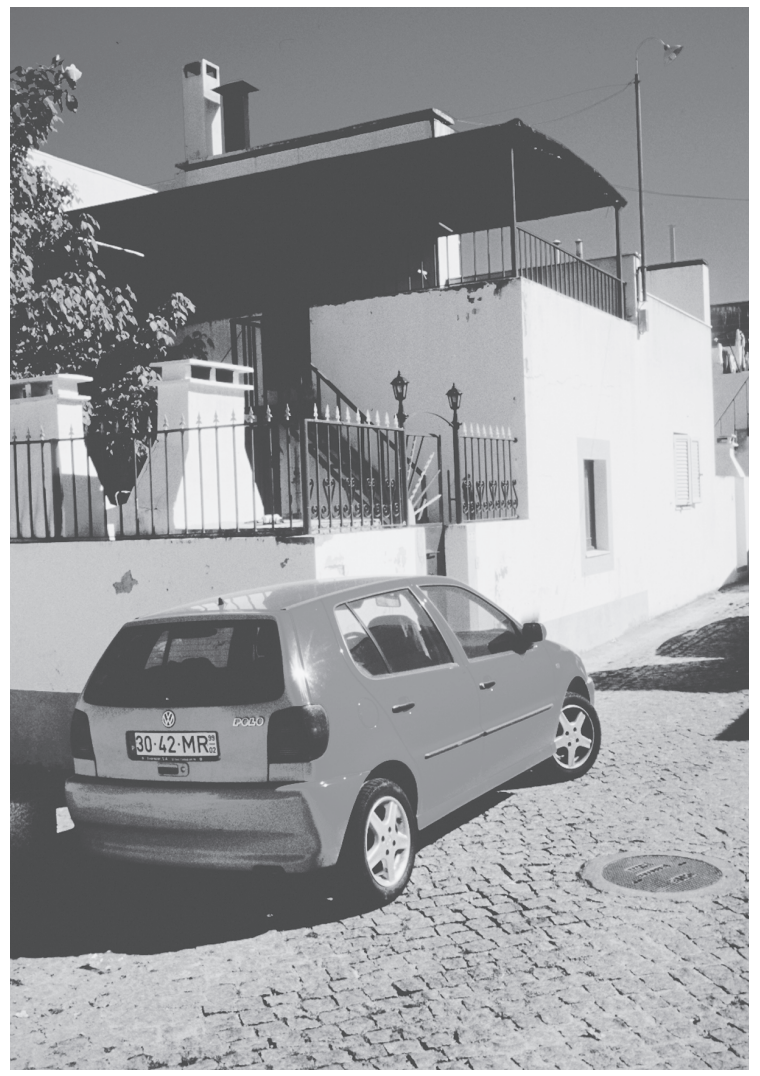

Consequência do muro baixo: a exposição do pátio e dos seus usos.

Foto de Jean-Michel Léger 


\section{Um Compromisso entre o Universal e o Singular}

Apesar do imenso trabalho realizado por José P. Duarte na reconstituição do trabalho de concepção e edificação da Malagueira, até hoje, nenhum estudo foi dedicado aos habitantes da Malagueira e aos modos de apropriação das suas casas. Neste sentido, esta pesquisa centra-se na avaliação dos usos que revelam como os habitantes, enquanto seguidores, continuadores ou destruidores da obra, validam ou não um projecto que não se reduz às intenções de Siza, mas é uma co-produção de um conjunto de actores institucionais e técnicos. O sucesso da Malagueira no mercado imobiliário de Évora é um bom indicador da pertinência do projecto, mas não é suficiente, uma vez que a má arquitectura vende-se igualmente muito bem.

O compromisso de Siza procura uma via entre uma posição racionalista, justificada por uma escolha ética e pela racionalização da concepção e da construção, e uma atenção às convenções e à arquitectura da casa. Com um território e uma quantidade de alojamentos semelhantes aos de um grande aglomerado, a Malagueira é completamente o oposto deste. Não é um modelo mas uma abordagem não reprodutível, porque específica a um contexto histórico, político e social - o alojamento em Portugal após o 25 de Abril - e um local - do bairro "clandestino" existente à topografia singular do terreno. Pelas suas referências, este projecto inscreve-se na grande história da arquitectura europeia após os anos 1920, sem ser um directo herdeiro do Siedlungen. É um projecto de múltiplas intenções (o aqueduto, as ruas estreitas, as tipologias evolutivas, as inovações técnicas) e simultaneamente muito flexível: em harmonia com a topografia do ter- reno e tecido pré-existente, assim como com as contradições entre o colectivo e o individual, assentando em tipologias passíveis de variações e evoluções. A Malagueira traz assim respostas inovadoras às contradições entre modernidade e convenção, entre pureza doutrinal e negociação com o local.

O conceito de tipologia evolutiva é validado pelos habitantes, que "entram neste jogo" que permite o aumento da casa; a elevação de certos muros inicialmente baixos dá igualmente razão a Siza, ao perceber o risco apresentado pelo muro baixo nas condições de um pátio pouco profundo e ruas estreitas. No exterior como no interior da casa, proximidade e "promiscuidade", guiam, com efeito, as práticas dos habitantes: se as transformações realizadas no rés-do-chão banalizam a delicada articulação pátio-lavandaria-cozinha-sala de jantar-sala de estar, é porque a necessidade fundamental de área suplementar obriga a reduzir e a encurtar o pátio, com vista a aumentar as divisões de maior uso na vida quotidiana.

Colocando a questão dos limites assente nos dois eixos da contiguidade lateral (relação com os vizinhos) e do pátio frontal (relação com a rua), as casas da Malagueira, como todas as casas em banda, perturbam a definição convencional de habitat individual. Embora contíguas e desprovidas da cave e do sótão tradicionais (Villanova, Leite, Raposo, 1995), elas possuem, no entanto, dois dos pré-requisitos que distinguem o habitat individual: uma porta individual e ausência de vizinhos, quer em acima quer em baixo. Assim, as casas em banda da Malagueira são casas adaptadas ao seu contexto urbano e económico, se admitirmos tal como Siza, que os habitantes fazem eles próprios também compromissos no limite das suas possibilidades. 


\section{Referências Bibliográficas}

BOHIGAS, O., HUET, B., GREGOTTI, V., 1976, "La Passion d'Alvaro Siza", L'Architecture d'Aujourd'hui, n. ${ }^{\circ}$ 185, Maio-Junho, pp. 42-43

BOUDON, Ph., 1985, Prefácio da segunda edição, aumentada, de Pessac de Le Corbusier. 1927-1967. Étude socio-architecturale, Paris, Dunod, (primeira edição: Dunod, 1969).

BOURDIEU, P., 2000, Les Structures sociales de l'économie, Paris, Ed. du Seuil.

CASTRO, A., 1995, "Ciganos e habitat: entre a itinerância e a fixação", Sociologia. Problemas e práticas, n. ${ }^{\circ}$ 17, pp. $97-$ $-111$.

CASTRO, A., 1998, "As construções dos emigrantes e a legitimidade de uma estética singular", Sociedade e Território, n. ${ }^{\circ} 25-26$, Fevereiro, "Mudança social e formas de habitar", pp. $80-86$.

COLLOVÀ, R., 1999, “Cronologie: Malagueira, Évora, 1974-2000", Lotus, n. ${ }^{\circ}$ 103, Dezembro, pp. 66-77.

CURTIS, W., 1994, "Alvaro Siza Vieira: an architecture of edges", in Alvaro Siza Vieira 1958-1994, Madrid, El Croquis, pp. 32-45.

DOMINGUES, A., LEITE, C., MATOS, F., 1999, De nouveaux desseins pour les coopératives d'habitation au Portugal, GEDES (Gabinete de Estudos de Desenvolvimento e Ordenamento do Território, Universidade do Porto-PUCA (Plan Urbanisme Construction Architecture).

EMERY, M., 1980, "La tranquille révolution d'Alvaro Siza", L'Architecture d'Aujourd'hui, n. ${ }^{\circ} 211$, Outubro, pp. 10-13

FONSECA FERREIRA, A., GUERRA, I., COSTA PINTO, T., 1990, "L'usage et l'appropriation du logement à Telheiras", Sociedade e Território, número especial "Portugal. Enjeux sociaux et transformations du territoire", Setembro, pp. 43-52 .

FRAMPTON, K., 2000, "Architecture as Critical Transformation: The Work of Alvaro Siza", in FRAMPTON, Kenneth (ed.), Alvaro Siza. Complete Works, Londres, Phaidon, pp. 11-65.
FRAMPTON, K., 1987, "Poesis et transformation: l'architecture d'Alvaro Siza", in Alvaro Siza. Profession poétique, Milan-Paris, Electa, pp. 10-24.

GUERRA, I., FONSECA FERREIRA, A., 1990, "Le mouvement 'clandestin' au Portugal - petites ressources, grands investissements", Sociedade e Território, número especial "Portugal Enjeux sociaux et transformations du territoire", Setembro, pp. 115-122.

HAUMONT, N., RAYMOND, H., 2000, L'Habitat pavilllonnaire, Paris, L'Harmattan (primeira edição: CRU, 1966).

HUET, B., GREGOTTI, V., BOHIGAS, O., 1976, "La passion d'Alvaro Siza", L'Architecture d'Aujourd'hui, n. ${ }^{\circ}$ 185, Maio-Junho, pp. 42-43.

JOSEPH, I., 1995, "Reprendre la rue", in JOSEPH I (ed.), Prendre place. Espace public et culture dramatique, Paris, Ed. Recherches/Colloque de Cerisy, pp. 11-35.

MOLTENI, E., 1997, Alvaro Siza. Barrio de la Malagueira, Évora, Textos i documents d'arquitectura, Sant Gugat del Vallès, Edicions Universitat politècnica de Catalunya.

MÓNICA, M. F., 1998, "Malagueira. Régua e esquadro", $I N D Y$, Suplemento de $O$ Independente, n. ${ }^{\circ} 506,23$ Janeiro, pp. 22-29.

PORTAS, N., 1987, "La recherche d'un langage", in Alvaro Siza. Profession poétique, Milan-Paris, Electa, pp. 40-45.

RAYMOND, H., 1984, L'Architecture, les aventures espaciales de la Raison, Paris, CCI - Centre Georges Pompidou.

RAYON, J.-P., 1982, “Quartier Malagueira. Évora”, Casabella, n. ${ }^{\circ} 478$, pp. 2-15.

SIZA, Á., 2000, Imaginar a evidência, Lisboa, Edições 70 (prefácio de V. GREGOTTI)

TESTA, P., 1984, The Architecture of Alvaro Siza, Thresholds Working Paper 4, Cambridge, MIT Department of Architecture.

VILLANOVA, R. de, LEITE, C., RAPOSO, I., 1995, Casas de Sonhos. Emigrantes construtores no Norte de Portugal, Lisboa, Salamandra.

ZAERA, A., 1994, "Salvando las turbulencias: entrevista con Alvaro Siza", in Alvaro Siza Vieira 1958-1994, Madrid, El Croquis, pp. 6-31. 